\title{
Role of Plant Tissue Cultures in International Exchange and Quarantine of Germplasm in the United States and Canada
}

\author{
Sarbagh Salih ${ }^{1}$ and Howard Waterworth ${ }^{2}$ \\ Fruit Laboratory/Plant Quarantine Office, U.S. Department of Agriculture, \\ Agricultural Research Service, Beltsville, MD 20705-2350 \\ Daniel A. Thompson ${ }^{3}$ \\ Centre for Plant Health, Canadian Food Inspection Agency, Sidney, BC, V8L 1H3, Canada
}

\begin{abstract}
Very few of the crops grown in the United States or Canada today evolved in North America. Ancestors of today's crops were brought to North America as the continent was being colonized (Waterworth, 1993). Although we enjoy an abundance of food, fiber, and aesthetic products, our crops are plagued by many production problems, including insects, diseases, weeds, and lack of crop tolerance to drought or poor soil conditions. Some crops cannot be mechanically harvested, yield poorly, or their products are highly perishable.

To deal with this broad range of adversi-
\end{abstract} ties, thousands of plant scientists are developing new cultivars that address aspects of the above problems. Foreign germplasm containing beneficial genes continues to be an important need of many genetics and breeding programs (White and Waterworth, 1996). Regrettably, hundreds of different kinds of insects and pathogens that exist overseas, and that have not yet invaded North America, could easily be imported with plant materials from other countries (Code of Federal Regulations, 2000; Foster, 1988; Kahn, 1979, 1986; Plant Protection Regulations, 1995; Waterworth, 1993). Among these pests are pathogens such as apple proliferation phytoplasma in pome fruits, and bacterial leaf blight of rice (Oryza sp.), which continue to cause immense losses in Europe (Waterworth, 1993) and Asia (Mew et al., 1988; Thurston, 1973).

Prior to the enactment of regulations to exclude foreign insects and diseases from North America, many were accidentally imported with plant germplasm, and are now so widespread that we think of them as indigenous. Such diseases and their casual agents include: cherry leafspot (Coccomyces hiemalis Higgins); apple scab [caused by Venturia. inaequalis (Cke.) Wint.]; cabbage black rot [Xanthomonas campestris pv. Campestris (Pammel) Dowson]; Dutch elm

Received for publication 19 July 2000. Accepted for publication 20 Dec. 2000. The cost of publishing this paper was defrayed in part by the payment of page charges. Under postal regulations, this paper therefore must be hereby marked advertisement solely to indicate this fact.

${ }^{1}$ Horticulturist. To whom requests for reprints should be addressed.E-mail address: pgqoss@ ars-grin.gov ${ }^{2}$ Lead Plant Pathologist, retired.

${ }^{3}$ Biologist. disease (Ceratocystis ulmi Buisman), and chestnut blight (Endothia parasitica Murrill). Among the insect pests imported are gypsy moth (Lymantria dispar L.), Japanese beetle (Popillia japonica Newman), and the sweet potato whitefly (Bremisia tabaci Gennadius). The many regulations now in place allow for the importation of prohibited plant materials from any part of the world, but under carefully controlled conditions (Code of Federal Regulations, 1999, 2000; Plant Protection Regulations, 1995). Plant samples are allowed to enter the United States and Canada, where they are inspected and then established in special quarantine greenhouses. While in quarantine these plants are observed for development of diseases, and tested for numerous virus and virus-like pathogens. These tests are required because infections by these agents on imported stock are usually not visible to inspectors.

In this review, we deal only with those genera that are in the most restrictive or prohibited quarantine category, viz., primarily those crops that are vegetatively propagated (Table 1). Among the categories of pathogens for which tests are conducted are viruses, viroids, phytoplasmas, and other unknown infectious agents (White and Waterworth, 1996). A significant percentage of the accessions, especially pome (Malus and Pyrus sp.) fruits and potatoes (Solanum sp.), received in the United States and Canada from many countries are infected with one or more of these pathogens (Table 2) (Kahn et al., 1979).

\section{PLANT GERMPLASM IN VITRO}

We use the term tissue-cultured plant germplasm (i.e., in vitro) to include any combination of cells, meristems, growing points, surface sterilized seeds, or entire plantlets growing on artificial media within aseptic containers. However, our focus is limited to its use in the international exchange of germplasm and especially its role while germplasm is in quarantine upon arrival in North America. Many authors have reviewed tissue culture applications in this regard (Majumdar, 1993; Parliman, 1986; Spiegel et al., 1993; Withers, 1988). Kahn (1979, 1986). Kahn and Mathur (1999) and Foster (1988) discussed the risks vs. benefits of exchanging germplasmbetween countries. Chor (1991) suggested that exchange of germplasm in vitro reduces the risk of spreading pests between countries, while Diekmann and Putter (1996) list specific steps to follow in collecting tree fruit germplasm for tissue culture. Withers (1988) lists more than 100 genera exchanged between countries as tissue cultures, in addition to a summary of participating countries, transport methods, and success rates.

Current and potential applications of tissue culture have been outlined in many publications (Ashmore, 1997; Bhojwani and Razdan, 1996; Debergh and Zimmerman, 1991; International Board for Plant Genetic Resources, 1988; Ng et al., 1992; Withers, 1988), while others described the shortcomings of exchanging quarantined germplasm via tissue culture (Ng et al., 1990; Parliman, 1986; Scowcroft, 1984). The topic of somaclonal variation re-

Table 1. Some genera that must pass through quarantine in North America and be tested for latent virus and virus-like pathogens ${ }^{\mathrm{z}}$.

\begin{tabular}{lcc}
\hline Genus & Country of origin & Primary pathogens \\
\hline Acer (some sp.) & Japan and Europe & Viruses \\
Aesculus & Czech Rep., Germany, Romania, UK & Viruses \\
Citrus & Ally & Canker, other diseases \\
Ipomoea & All & Viruses, phytoplasmas \\
Malus/Pyrus & All & Viruses, viroids, phytoplasmas \\
Manihot & All & Several insects and pathogens \\
Poaceae (all except Bambuseae) & All & Viruses, spiroplasmas, virus-like agents \\
Prunus & All & Viruses, phytoplasmas, virus-like agents \\
Ribes & Europe & Currant reversion virus \\
Solanum (tuber-bearing sp.) & All & Viruses, viroids \\
Sorbus & Czech Rep., Denmark, Germany & Viruses \\
Ulmus & Europe & Elm mottle virus \\
Vitis & All & Viruses, virus-like agents \\
\hline
\end{tabular}

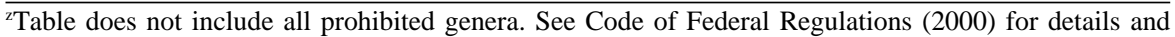
exceptions.

${ }^{y}$ Except exchanges between the United States and Canada, which have less restrictive quarantines. 
Table 2. Status of virus-like disorders among quarantined genera in the United States and Canada.

\begin{tabular}{lcc}
\hline \hline & $\begin{array}{c}\text { No. of virus-like } \\
\text { pathogens for } \\
\text { which tests } \\
\text { are conducted }\end{array}$ & $\begin{array}{c}\text { Accessions } \\
\text { infected } \\
(\%)^{\mathrm{y}}\end{array}$ \\
\hline Cassava & 7 & 2 \\
Currant & 9 & 4 \\
Grasses & 35 & 5 \\
Pome fruit & 26 & 50 \\
Potato & 29 & 48 \\
Raspberry & 20 & 60 \\
Shade trees & 22 & 2 \\
Stone fruit & 40 & 20 \\
Sugarcane & 7 & 2 \\
Sweetpotato & 4 & 48 \\
Woody shrubs $^{\mathrm{w}}$ & 38 & 2
\end{tabular}

${ }^{2}$ Includes phytoplasmas and noncharacterized viruslike pathogens.

${ }^{y}$ Data from Kahn et al. (1979).

'Includes species of Acer, Aesculus, Sorbus, and Ulmus.

"Includes species of Jasminum, Ligustrum, Rosa, Syringa, Euonymus, and Philadelphus.

sulting from tissue-cultured germplasm has also been reviewed (Bhojwani and Razdan, 1996; Debergh and Zimmerman, 1991; Nehra et al., 1992). Spiegel et al. (1993) and George (1996) described many biotechnology-based methods that have potential for use in detecting viruses in plant germplasm. Finally, there are reports on individual crops, including descriptions of pathogens, diseases, methods, media and procedures, such as those on sweet potato (Ipomoea sp.) (Beetham and Mason; 1992), stone fruits (Prunus sp.) (Diekmann and Putter, 1996), citrus (Kahn and Mathur, 1999), and rice (Mew and Misra, 1994).

Several of the International Agriculture Research Centers, such as the International Center for Tropical Agriculture (potato) and the International Institute of Tropical Agriculture

Table 3. Modes of detection ${ }^{2}$ of pests of quarantine interest by inspection of samples of imported tissue cultures in the United States and Canada. Modified from Kahn (1986).

\begin{tabular}{|c|c|c|c|c|}
\hline \multirow[b]{2}{*}{ Pest groups } & \multicolumn{2}{|c|}{ Observation of plants } & \multicolumn{2}{|c|}{ Contamination of the media } \\
\hline & Signs $^{y}$ & Symptoms $^{x}$ & By pest ${ }^{w}$ & By nonpest $^{v}$ \\
\hline Insects & + & - & - & + \\
\hline Mites & + & - & - & + \\
\hline Nematodes & - & - & - & + \\
\hline Bacteria (nonfastidious) & - & \# & + & - \\
\hline Fungi & \# & \# & + & - \\
\hline Viruses and viroids & - & - & - & - \\
\hline Phytoplasmas & - & - & - & - \\
\hline Spiroplasmas & - & - & - & - \\
\hline Protozoa & - & - & - & - \\
\hline
\end{tabular}

${ }^{2}$ If present upon inspection: $+=$ the pest would be detected; $-=$ the pest would not be detected; $\#=$ some pests in the group might be detected but only with difficulty.

${ }^{\mathrm{y}}$ Observation of the pest directly.

${ }^{x}$ Absence of symptoms does not necessarily mean absence of the pest because of long incubation periods or latency.

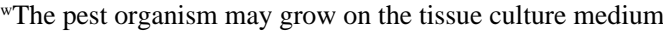

vThe pest organism might carry nonplant pest organisms that may contaminate the medium. Presence of a nonpest contaminant might suggest the presence of a pest or a failure in aseptic procedure.

[cassava (Manihot sp.), sweet potato] (Withers, 1988), have shipped germplasm in the form of tissue cultures for many years. However, as mentioned earlier and as cautioned by Kahn (1986), these shipments are not without hazard. The apparent absence of pests, based upon visual inspection, is no assurance that all dangerous pathogens are absent. Kahn categorized germplasm in tissue culture into four groups based upon pest type, signs of insects, their eggs, nematodes, fungal or bacterial growth, and symptoms indicating the presence of a pathogen in the plant at the time of visual inspections (Table 3). As the table shows, many categories of disease agents are not readily detected by visual observation, and thus they must be assayed for such pests. These include endophytic contaminants occurring intracellu- larly and intercellularly, surface contaminants not readily amenable to surface sterilants, and contaminants introduced through faulty techniques. Cassells (1992) described some of the procedures for screening in vitro germplasm for these contaminating microorganisms.

\section{ROLE OF TISSUE CULTURE IN NORTH AMERICAN QUARANTINE PROGRAMS}

\section{Exchange of germplasm}

Vegetative accessions of potato germplasm enter the United States either as tubers, or similar to sweet potatoes, as plantlets in tissue culture (Fig. 1A, Table 4). If no pests or

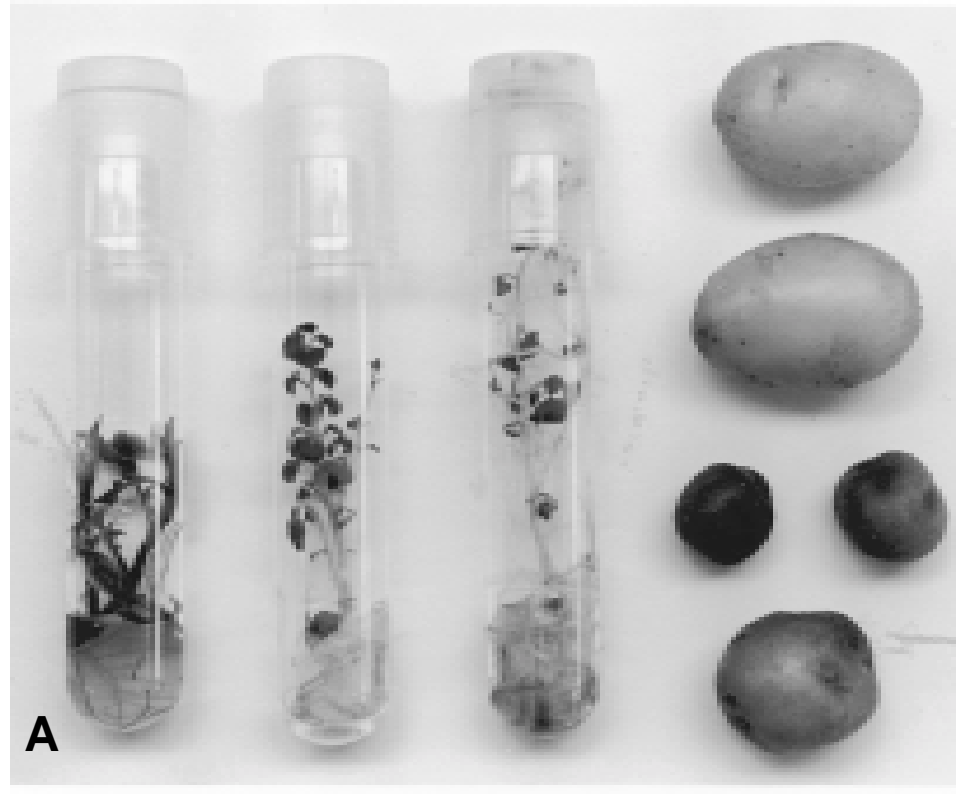

Fig. 1. (A, above) Typical importation of potato germplasm in vitro under sterile conditions, and as tubers. (B, right) Typical accession of virus-tested potato germplasm transferred to $5 \%$ agar ready for shipping.

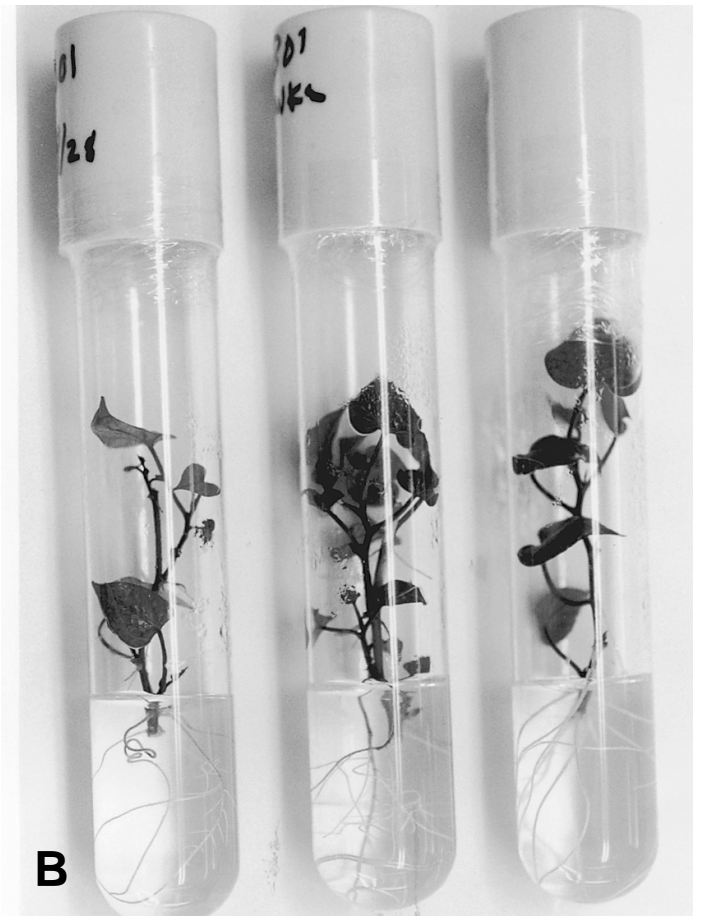


Table 4. Role of tissue culture in processing accessions of selected crops through quarantine.

\begin{tabular}{lcccccc}
\hline Crop & $\begin{array}{c}\text { Import/export } \\
\text { germplasm }\end{array}$ & $\begin{array}{c}\text { Produce } \\
\text { indicators }\end{array}$ & $\begin{array}{c}\text { Back-up to } \\
\text { potted plants }\end{array}$ & $\begin{array}{c}\text { Produce } \\
\text { pathogen-free } \\
\text { germplasm }\end{array}$ & $\begin{array}{c}\text { Maintain } \\
\text { virus-infected } \\
\text { cultures }\end{array}$ & $\begin{array}{c}\text { Source of } \\
\text { tissue for tests }\end{array}$ \\
\hline Cassava & $\mathrm{X}$ & $\mathrm{X}$ & $\mathrm{X}$ & --- & $\mathrm{X}$ & --- \\
Currant & $\mathrm{X}$ & --- & --- & --- & $\mathrm{X}$ & --- \\
Pome fruit & $\mathrm{X}$ & --- & --- & --- & $\mathrm{X}$ & --- \\
Potato & $\mathrm{X}$ & --- & $\mathrm{X}$ & $\mathrm{X}$ & $\mathrm{X}$ & $\mathrm{X}$ \\
Raspberry & ---- & --- & $\mathrm{X}$ & --- & --- & --- \\
Rice & --- & --- & --- & $\mathrm{X}$ & --- \\
Stone fruit & $\mathrm{X}$ & $\mathrm{X}$ & --- & --- & -- & -- \\
Sugarcane & $\mathrm{X}$ & --- & --- & -- & - \\
Sweet potato & $\mathrm{X}$ & $\mathrm{X}$ & $\mathrm{X}$ & $\mathrm{X}$ & & - \\
\hline
\end{tabular}

pathogens are observed upon initial inspection, the germplasm is established in preparation for tests for latent viruses and viroids. Germplasm arriving in tissue culture is immediately subcultured by transferring shoots individually into several culture tubes and allowing them to grow into 10 - to $15-\mathrm{cm}$-tall plants. When received as tubers or fleshy roots, accessions are planted, and six to eight growing points from shoots are placed individually on artificial media. Somaclonal variation is favored in cultures when high concentrations of growth regulators are used (Sansavini et al., 1990). We manage this potential problem by employing low concentrations of growth regulators and discarding plantlets showing changes, such as leaf color or reduction in size of plants. Those that develop from callus, as opposed to meristems, are also discarded if irregularities are noted. Nehra et al. (1992) for example, noted that variants from strawberry (Fragaria ¥ananassa Duch.) arose only from callus, not from meristem tips.

For potato and sweet potato, we select the most vigorous plantlet in tissue culture for pathogen testing. This plantlet is subcultured to four to six tubes, two of which are accli- mated to growing in a soilless rooting medium and from which leaves are harvested for virus tests. If no pathogens are detected, three to five of the sister plantlets are transferred to a 5\% agar medium on which they are shipped to the importer or to the respective germplasm repository (Fig. 1B). Shoots are less apt to be damaged during transit when on this firm medium.

Cassava germplasm usually arrives as plantlets or shoots in tissue culture but occasionally as cuttings to be rooted. After visual inspection, the cuttings are placed in soilless rooting media, such as perlite, under mist. A plantlet of each accession in tissue culture is divided by transferring up to six growing points individually to fresh media. When tests for viruses are completed, the plantlet on which virus tests were conducted is divided and transferred onto 5\% agar medium; after several weeks plantlets are shipped to the importer. Only rarely has stone fruit, pome fruit, currant (Ribes sp.), grape (Vitis sp.), or sugarcane (Saccharum sp.) germplasm been received as tissuecultured plantlets. However, when it is, the plantlets are acclimated to soilless media for growing in the greenhouse and testing for pathogens.

\section{Production of virus indicator test plants}

Some of the virus-sensitive indicators onto which imported germplasm is grafted and observed for the development of disease symptoms are not available from North American commercial sources. However, these genotypes are often named in the world literature as the best of several evaluated for displaying symptoms of virus-like diseases. In a few instances, the only indicator known may be the genotype in which the disease was originally described. In some of these situations, plants of the virus indicator are produced from virusfree plants maintained in tissue culture. For example, the indicator cultivars Baldwin and Amos Black of Ribes nigrum L., to which accessions of currants are grafted, are produced in tissue culture, as are the indicators 'Norfolk Giant', Ipomoea setosa L. (Fig. 2A), and cassava (Manihot utilissima Pohl.) cv. Secundina for use in testing accessions of raspberries (Rubus sp.), sweet potatoes and cassava, respectively. Likewise, virus-free pome fruit rootstocks onto which new accessions are grafted, such as Malus sylvestris Mill. 'M.26', Pyrus communis L. clone OH x F 51, or stonefruit stocks Prunus avium L. cv. Mazzard and clone F12/1, and $P$. insititia (L.) C.K. Schneid 'St Julian A', are produced in vitro in Canada. One advantage of producing indicators and roostock onsite by tissue culture is that plants are available throughout the year, and in the quantity needed.

\section{Provide source of tissues for virus tests}

Plant tissues in aseptic cultures have been employed in many types of screening and evaluation programs such as determining susceptibility to plant pathogens, resistance to herbicides, or salt tolerance (Bhojwani and Razdan, 1996; Debergh and Zimmerman,
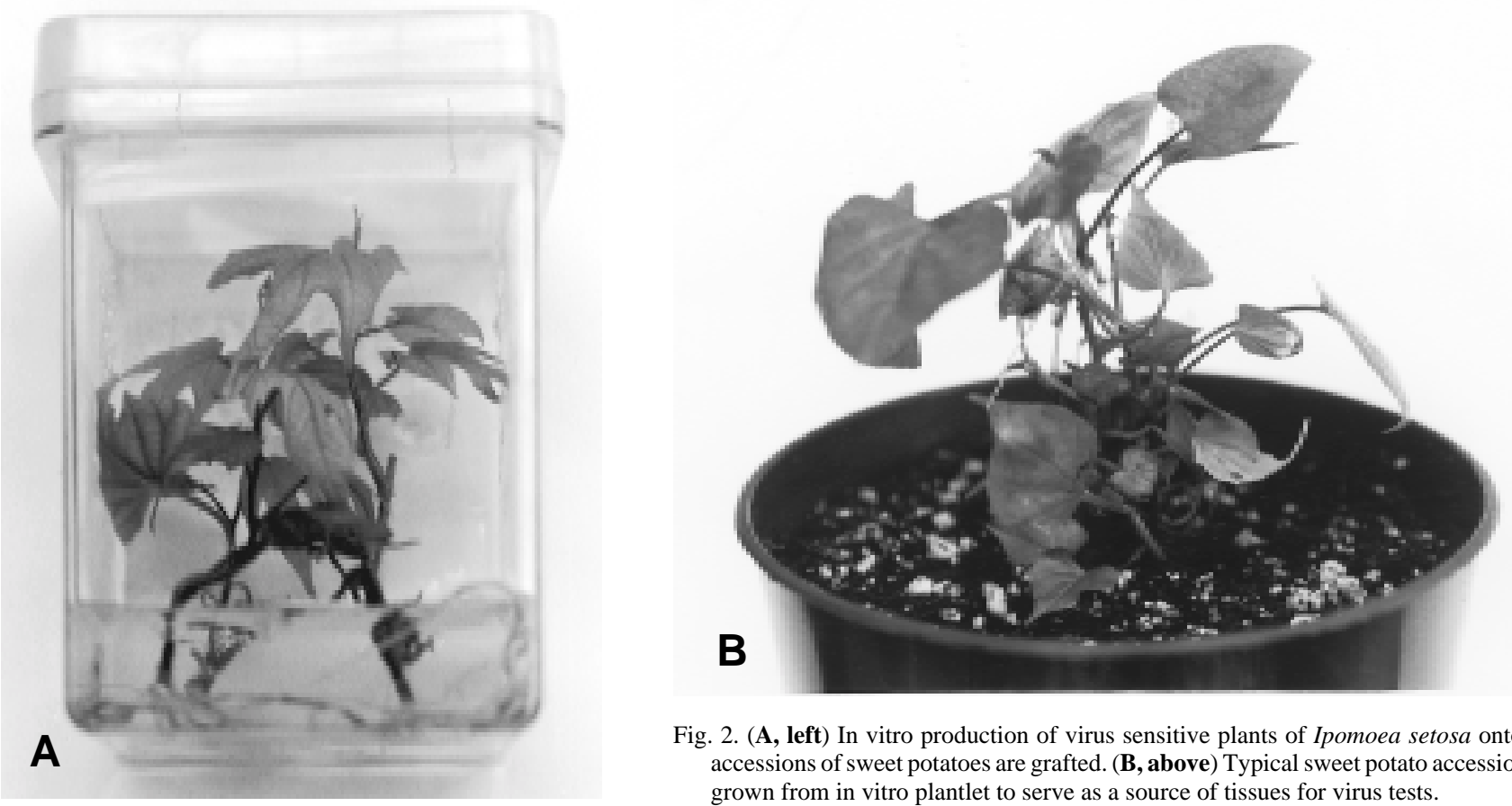

Fig. 2. (A, left) In vitro production of virus sensitive plants of Ipomoea setosa onto which accessions of sweet potatoes are grafted. (B, above) Typical sweet potato accession plants grown from in vitro plantlet to serve as a source of tissues for virus tests. 
1991). However, with few exceptions (Baumann et al., 1984; Singh et al., 1996), in vitro cultures have not been widely used as sources of tissues on which to conduct tests for pathogens (da Camara Machado et al., 1998). Most of our tests are performed ex vitro on plants that have been established from the imported germplasm. Depending on the genus, we employ a combination of testing methods, such as enzyme-linked immunosorbent assay (ELISA), polymerase chain reaction (PCR), electron microscopy, and grafting to sensitive indicator plants to detect the many different virus and virus-like pathogens that may be present in imported germplasm. All but grafting could be developed to utilize tissues directly from tissue culture material. Progress is underway toward this end.

For example, in the U.S. program, the PCR procedure is being evaluated to detect feathery mottle geminivirus in sweet potatoes utilizing tissues directly from artificial media. Tests for other viruses affecting these genera are also performed on plantlets propagated in vitro after they have been potted and grown to a size where adequate amounts of tissue can be harvested for the various tests (Fig. 2 B). With pome fruits, meristem tips $0.5 \mathrm{~mm}$ tall are dissected from heat-treated, infected germplasm, then grown on media containing an antiviral chemical. When shoot tips are 2 to $4 \mathrm{~cm}$ tall, they are micrografted onto small, potted, seedling rootstocks. When large enough they become the source of buds on which to conduct graft tests to verify elimination of viruses as a result of tissue culture therapy. Similar experiments are in progress with regard to the stone fruits. Plans are also underway to evaluate in vitro tissues as a source to detect phytoplasmas in pome fruits.

\section{Provide back up in case of loss}

Imported germplasm often cannot be replaced if it dies while in quarantine because it originates from such sources as wilderness areas or from markets in other countries where collectors encounter it by chance. Even if successfully established, a number of situations can occur during the 12 to 48 months in quarantine that adversely affect these crops. Crops such as currants, raspberries and tree fruits must undergo chilling to break dormancy. They are grown in unheated screen houses and occasionally do not survive the winter season. Some genotypes are extraordinarily susceptible to domestic pests or diseases and grow poorly. Still others are sensitive to growing conditions, such as water supply, soil pH, fertility, and pesticides. Any of these factors may cause death. For these reasons, accessions of potatoes, sweet potatoes, currants, raspberries, and cassava are duplicated as several plantlets in tissue culture and transfers made to fresh media as necessary, until they are released from quarantine and distributed to the importers (Fig. 3).

\section{Therapy on virus-infected accessions}

A considerable percentage of some genera are infected with one or more virus-like pathogens (Table 2). Although many of the

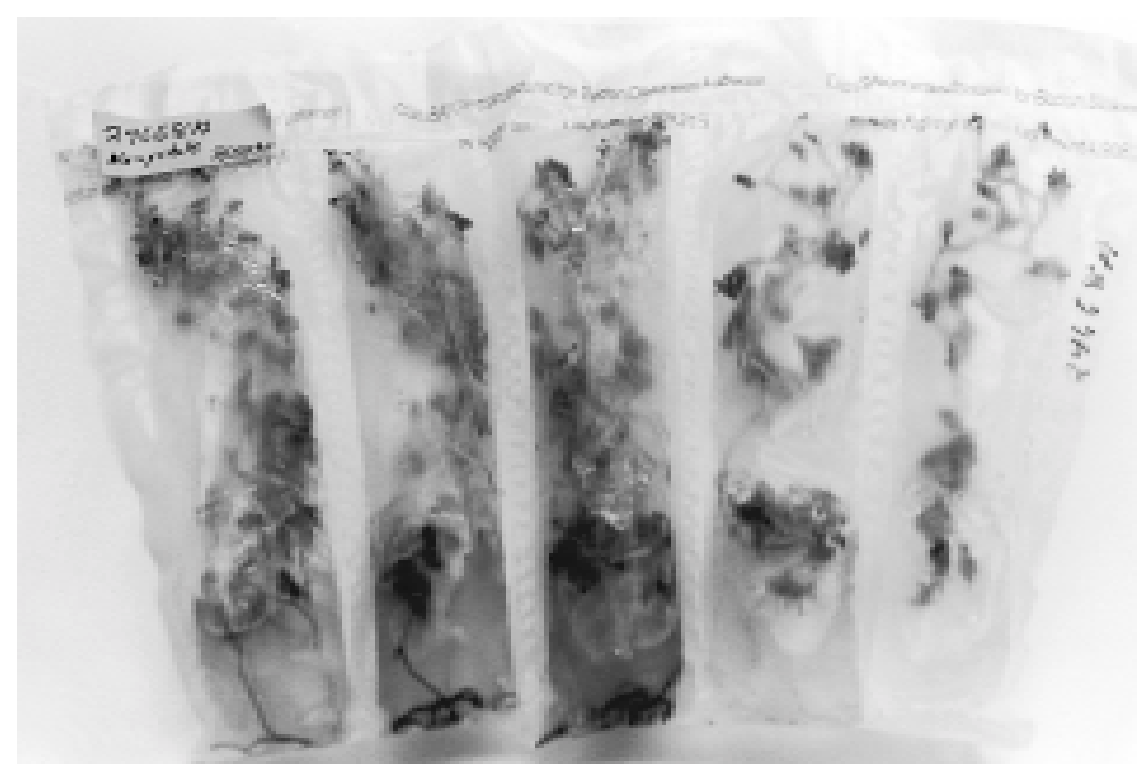

Fig. 3. Plants of Rubus sp. stored in sterile plastic culture bags.

viruses detected in imported germplasm already exist in North America, distribution of only virus-free germplasm within our countries and to persons overseas is preferred. In some instances, only the pollen or seed from an infected plant is needed by the importer to meet a research objective. Since these may or may not contain virus, they are distributed and the source plant destroyed. However, in most cases, only vegetative propagules can fulfill research or genotype evaluation needs. Therefore, efforts are made to obtain virusfree vegetative material from infected plants.

A considerable body of literature deals with methods for obtaining virus free plants from infected mother plants utilizing cultured tissues. The procedures employed can be categorized into four approaches. Some reports focus on the use of antiviral chemicals (Hansen, 1989). For example, James et al. (1997) reported elimination of apple stem grooving virus by chemotherapy without heat treatments. Others took the opposite approach; Knapp et al. (1997) and da Camara Machado et al. (1998) eliminated several viruses from pome and stone fruit utilizing heat treatments without use of antiviral chemicals. Postman et al. (1995) eliminated viroids from pome fruit tissues by exposure to alternating high and low temperature. Still others combined heat treatments with chemotherapy to produce virus-free tissues. For example, Deogratias et al. (1989) eliminated several viruses from heat-treated pome and stone fruits by subculturing shoots eight or nine times onto media with high concentrations of antiviral chemicals. Sanchez et al. (1991) eliminated several viruses from potatoes by employing various combinations of heat-treatment and chemotherapy. Finally, virus-free plants can be produced without heat treatments or chemicals because some viruses are not fully systemic throughout an entire plant; and that by isolating several growing points or lateral buds, some may remain virus-free. Bhojwani and Razdan (1996) and George
(1996) described several variations on the isolation of meristematic cells or meristems, and listed many examples of viruses eliminated by this approach. Faccioli and Marani (1998) reviewed meristem tip culture and in vitro tip micrografting to produce virus-free plants. Nonetheless, use of a combination of these approaches (heat, antiviral chemicals, and meristem tip isolation) usually produces a higher percentage of virus-free propagules and, for some virus-like pathogens, is the only successful protocol that succeeds (Deogratias et al., 1989; Ng et al., 1992; Spiegel et al., 1993). Bhojwani and Razdan (1996) list 47 genera from which viruses have been eliminated by using tissue culture.

In our programs, a combination of treatments are utilized in order to obtain pathogen-free germplasm; they include heat treatments, isolation of meristem tips, and use of ribavirin, ('Virazole') 1-b-D-ribofuranosyl1,2,4-triazol-3-carboxamide (Sigma Chemical Co., St. Louis), in the culture medium. Typically, when a virus is detected in accessions of potatoes or sweet potatoes, a plantlet is divided by transferring several growing points individually onto media containing ribavirin (Fig. 4A). The propagules are then subjected to cycles of $4 \mathrm{~h}$ at $35^{\circ} \mathrm{C}$ in the light, and $4 \mathrm{~h}$ at $31^{\circ} \mathrm{C}$ in the dark continuously for 4 to 6 weeks, depending on how well the plants grow under these stressful conditions. Following ribavirin (for sweet potato), or ribavirin plus heat therapy (for potato), several meristem tips are dissected and transferred individually to fresh media and allowed to develop into plants. The tests for viruses are repeated on the most vigorous plantlet after acclimation and growth in the greenhouse. If the pathogen has not been eliminated, the thermal therapy cycle and the virus tests are repeated. By this procedure, virus-free germplasm has been obtained from most accessions. Cultured tissues are also utilized to eliminate viruses from pome and stone fruit accessions. Nearly 50 pome and 

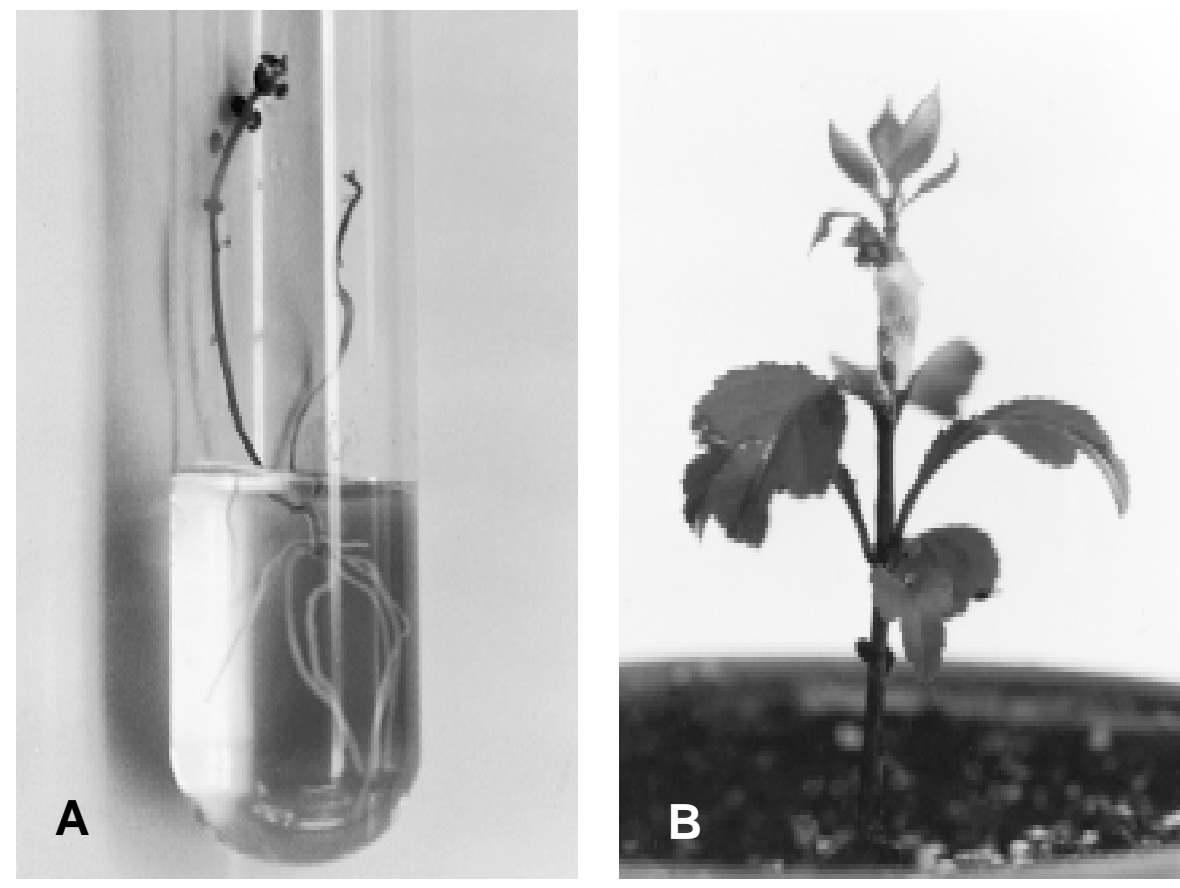

placed in a clean packet. Seed is then de-hulled and surface sterilized in commercial bleach diluted 1:10 for $2 \mathrm{~h}$ without rinsing, and placed onto nutrient agar in tubes under sterile conditions. The medium used supports growth of any internal pathogens. After 2 weeks, tubes displaying microbial growth are destroyed. Healthy seedlings, now 6 to $9 \mathrm{~cm}$ tall (Fig. $5 \mathrm{~A}$ ), are acclimated and transplanted to pots in the greenhouse where they are observed for symptoms of disease (Fig. 5B). The new seed from disease-free plants is considered pathogen-free and is distributed.

\section{PROBLEMS ASSOCIATED WITH TISSUE CULTURES}

Although international exchange of germplasm in vitro offers many useful roles, it is not without its limitations ( $\mathrm{Ng}$ et al., 1992; Parliman, 1986). Technology is not yet available to grow, maintain, and differentiate cultured tissues of some genera into plants. The importance of a well-equipped laboratory and trained staff is also essential (Bhojwani and Razdan, 1996; Debergh and Zimmermann, 1991), and is a limitation in many countries (Ashmore, 1997). Love et al. (1987) described the appreciable problem of contamination of tissue cultures by numerous fungal and bacterial pathogens, which have limited the adoption of this means of international exchange.

They also stated that low survival of excised meristems has been a deterrent to the use of tissue culture. Furthermore, different genera, species, or even cultivars within a species, require different media (Bhojwani and Razdan, 1996; Debergh andZimmerman, 1991; George, 1996). Scowcroft (1984) described the problems of tissue culture instability and somaclonal variation, as well as the origin and impact of these phenomena, which are exacerbated under in vitro conditions. Another problem with tissue culture is that exchange of germplasm in vitro gives a false sense of health when, in fact, it may be infected with latent virus-like pathogens. Furthermore, as Withers (1988) cautioned, some contaminating fungi and bacteria will not be visible on media that are formulated specifically for growth of higher plants. Finally, tissue culture is seldom used in the deciduous tree fruit industry or by plant breeders. This means that germplasm in this form must be converted back to potted trees from which budwood can be collected for large scale propagation or production of flowers for breeders. This process requires several years to complete. several potato viruses, and many more, are not known to occur in North America. Some pathogens are spread by insects or mites, but other means of transmission are not known. These pathogens are obligate parasites in that they can survive only in living tissues. For these reasons, it is prudent to maintain them, not in potted plants, but in tissues or plantlets within the confines of test tubes. Isolates of plum pox virus (Lansac et al., 1998) have been successfully maintained in vitro. Currant reversion and plum pox viruses are also maintained in this manner at the Canadian Centre for Plant Health. Usually this method is not practical if

budwood is required as the source of inocuphytoplasmas tohealthy rootstocks as ascit ing method for resistance in Malus and Prunus

\section{Detect pathogens on accessions of}

Seeds of several major North American crops, such as corn (Zea mays L.), cotton (Trosspium hirsutum L.), wheat (Tritic (L.) Moench], are prohibited entry except 1979). Many of these pathogens are not known to occur in North America and some are responsible for epidemics in other countries. Rice is another crop whose imported seed must be grown under quarantine conditions (Code of Federal Regulations, 1999) because of seed-borne diseases in other countries (Mew et al., 1988, 1990; Thurston, 1973). Among the pathogens named in regulations or of special concern to growers are species of fungi that cause leaf smut disease (Entyloma sp.), downy mildew (Sclerospora sp.), glume blotch (Melanomma sp.), and blight (Oospora sp.) (Code of Federal Regulations, 1999).

Some 200 to 300 packets of rice seed are processed through U.S. quarantine annually. Tissue culture has a significant role in insuring that no pathogen escapes detection and becomes established in the United States. The seeds of each accession are inspected and held in water at $56{ }^{\circ} \mathrm{C}$ for $15 \mathrm{~min}$, air-dried, and

\section{FUTURE ROLE OF IN VITRO GERMPLASM IN QUARANTINE}

International exchange via tissue culture has become a significant means of sharing plant germplasm, especially in crops such as sweet potatoes, potatoes, and cassava (Chandra, 1993). Withers (1988) listed 135 genera exchanged in vitro among some 50 countries through 1985 . The many roles of tissue culture as a tool to collect germplasm and to process it through quarantine have been described (In- 

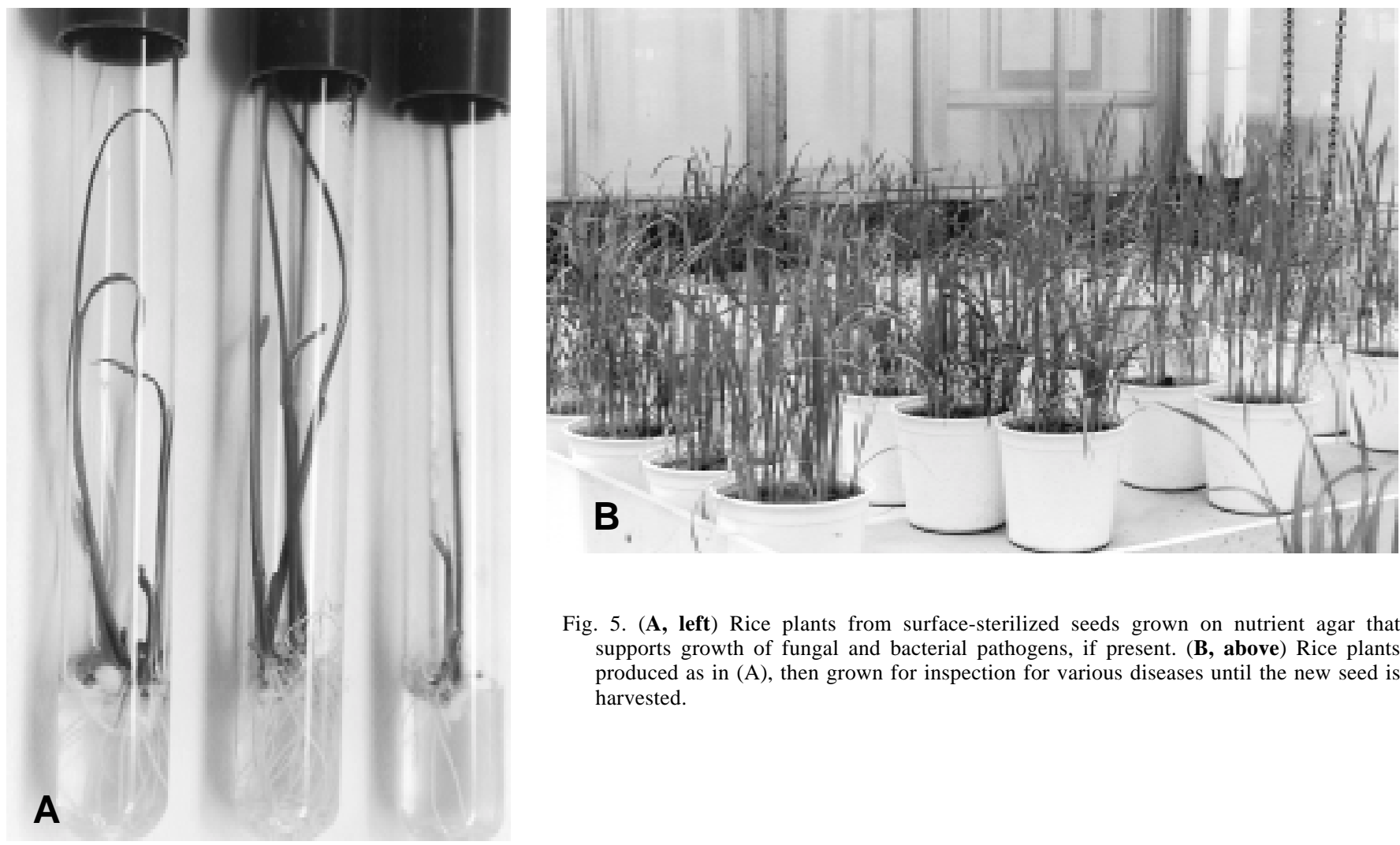

Fig. 5. (A, left) Rice plants from surface-sterilized seeds grown on nutrient agar that supports growth of fungal and bacterial pathogens, if present. (B, above) Rice plants produced as in (A), then grown for inspection for various diseases until the new seed is harvested.

ternational Board for Plant Genetic Resources, 1988; Kahn, 1986; Withers, 1988). One can expect that exchange via in vitro culture will assume an ever-expanding role in meeting quarantine objectives. Among the obvious benefits are reduced risks of moving pathogens and insects with the germplasm because the consignment is small, having originated from meristematic tips or buds, and because the aseptic plantlet system has some built-in pathogen detection capabilities. Cultures free of fungal or bacterial growth are free of pathogens except obligate parasites, such as rusts, viruses, and certain fastidious organisms (International Board for Plant Genetic Resources, 1988; Kahn, 1979, 1986; Kahn and Mathur, 1999). For these reasons, the quarantine regulations of some countries have been made less restrictive (Miller-Jones, 1986) when germplasm is imported in the form of tissue cultures (Ng et al., 1992; Withers, 1988). However, because there is no assurance that tissue cultures are free of pathogens, especially viruses, viroids and phytoplasmas, quarantine regulations of the United States and Canada do not differentiate between imports of in vitro vs. in vivo plant propagules. International approval of additional foreign virus testing programs, in conjunction with acceptable tissue culture techniques, would expedite exchange of germplasm.

New tissue culture procedures also hold considerable promise for obtaining pathogenfree germplasm from infected mother plants. We can expect that expanded manipulations of tissue cultures, combined with temperature and chemical therapy, will result in eliminating some of the recalcitrant viruses, viroids, phytoplasmas, and other infectious agents. For example, Brison et al. (1997) froze infected cultured tissues of Prunus sp. at $-40^{\circ} \mathrm{C}$, eliminating plum pox virus in $50 \%$ of the shoot tips and resultant plants. Use of additional antiviral chemicals holds promise as an effective means of producing virus-free plantlets in vitro.

Cultured tissues will also become more widely adopted as the source of tissues on which to conduct tests for pathogens. As new diagnostic technologies that require very small amounts of tissues become available, we can expect that they will be utilized for routine use on large numbers of quarantined samples. Singh et al. (1996) employed ELISA, nucleic acid hybridization, and a dot immuno binding assay to detect several viruses in potato cultures, while Baumann et al. (1984) detected two viruses by ELISA tests in sour cherry (Prunus cerasus L.) plantlets cultured in vitro. da Camara Machado et al. (1998) described procedures to detect two common viruses of apples in in vitro plants. Monette et al. (1990) readily sap-transmitted grapevine virus $\mathrm{A}$, which was previously transmissible only with difficulty, from grapevine tissue cultures to Nicotiana benthamiana Domin. Tissue cultures may even lend themselves to new ways of detecting pathogens. For example, exocortis viroid in citrus was detected by the callusing and rooting reaction of stem pieces in cultures (Navarro, 1981).

The value of cultured tissues as a source of samples for tests for pathogens offers additional benefits. For example, there is no limit on the time of year in which tests can be conducted because growing conditions, such as temperature and light, can be controlled. Tissue cultures require much less space than do potted plants and the problem of insect and mite control can be averted. There can be no doubt that cultures of plant tissues will assume a more significant role in the international exchange and quarantine of germplasm in the future.

\section{Literature Cited}

Ashmore, S.E. 1997. Status report on the development and application of in vitro techniques for the conservation and use of plant genetic resources. Intl. Board for Genetic Resources, Rome.

Baumann, G., R. Casper, and P. Kornkamhaeng. 1984. Detection of prune dwarf virus by ELISA in meristem-propagated sour cherry plants during in vitro culture. Phytopath. Zeit. 110:110-116.

Beetham, P. and A. Mason. 1992. Production of pathogen-tested sweet potato. Aust. Ctr. Intl. J. Agr. Res. Tech. Rpt. No. 21.

Bhojwani, S.S. and M.K. Razdan. 1996. Plant tissue culture. Theory and practice. Elsevier, Amsterdam

Brison, M., M-T. De Boucaud, A. Pierronnet, and F. Dosba. 1997. Effect of cryopreservation on the sanitary state of a cv. Prunus rootstock experimentally contaminated with plum pox potyvirus. Plant Sci. 123:189-196.

Cassells, A.C. 1992. Screening for pathogens and contaminating micro-organisms in micropropagation, p. 179-192. In: J. M. Duncan and L. Torrance (eds.). Techniques for the rapid detection of plant pathogens. Blackwell Science, Oxford.

Chandra, R. 1993. Tissue culture in exchange of potato germplasm. Intl. Board for Genetic Resources, Nwsl. for Asia, the Pacific and Oceania No. 13. 
Chor, C. K. 1991. Plant quarantine guidelines for in vitro germplasm exchange, p. 127-133. In: A. Zakri, M. Norman, and M. Senawi (eds.). Conservation of plant genetic resources through in vitro methods. Proc. In: Intl. Wkshp. on Tissue Culture for the Conservation of Biodiversity, Kuala Lumpur. Forest Res. Inst. of Malaysia.

Code of Federal Regulations. 1999. Foreign quarantine notices. Subpart 319.55-Rice. Title 7-Agriculture, Ch. III, Animal Plant Health and Inspection Serv.

Code of Federal Regulations. 2000. Foreign quarantine notices: Subpart 319.37-Nursery stock, plants, roots, bulbs, seeds and other plant products. Title 7-Agriculture, Ch. III, Animal Plant Health and Inspection Serv.

da Camara Machado, A., D. Mendonca, M.S. Lopes, E. Knapp, V. Hanzer, W. Arthofer, H. Katinger, and M.L. da Camara Machado. 1998. Phytosanitary improvement of fruit tree species: Diagnostic strategies in virus indexing of in vitro plants. Acta Hort. 472:511-516.

Debergh, P.C. and R.H. Zimmerman. 1991. Micropropagation technology and application. Kluwer Academic, Dordrecht, The Netherlands.

Deogratias, J.M., F. Dosba, and A. Lutz. 1989. Eradication of prune dwarf virus, Prunus necrotic ringspot virus, and apple chlorotic leafspot virus in sweet cherries by a combination of chemotherapy, thermotherapy, and in vitro culture. Can. J. Plant Path. 11:337-342.

Diekmann, M. and C.A. J. Putter. 1996. FAO/ IPGRI technical guidelines for safe movement of germplasm. No.16. Stone fruits. Food and Ag. Organization of the United Nations, Rome.

Faccioli, G., and F. Marani. 1998. Virus elimination by meristem tip culture and tip micrografting, $\mathrm{p}$. 346-389. In: A. Hadidi, R.K. Khetarpal, and H. Koganezawa (eds.). Plant virus disease control. APS Press, St. Paul, Minn.

Foster, J.A. 1988. Recommendations for improvements in the international exchange of temperate fruit tree germplasm, p. 27-30. In: Rpt. on in vitro storage conf. Advisory committee on in vitro storage, Intl. Board for Plant Genetic Resource. Rome.

George, E.F. 1996. Plant propagation by tissue culture. Part I: The technology; Part II: In Practice. Exegetics Ltd, Somerset, England.

Hansen, A.J. 1989. Antiviral chemicals for plant disease control. Crit. Rev. Plant Sci. 8:45-88.

International Board for Plant Genetic Resources. 1988. Conservation and movement of vegetatively propagated germplasm: In vitro culture and disease aspects Rpt. on in vitro storage conf. Advisory committee. p. 1-11. In: Intl. Board for Plant Genetic Resources. Rome.

James, D., P.A. Trytten, D.J. MacKenzie, G.H. N. Towers, and C.J. French. 1997. Elimination of apple stem grooving virus by chemotherapy and development of an immunocapture RTPCR for rapid sensitive screening. Annu. Appl. Biol. 131:459-470.

Jarausch, W., M. Lansac, C. Bilot, and F. Dosba 1999. Phytoplasma transmission by in vitro graft inoculation as a basis for a preliminary screening method for resistance in fruit trees. Plant Pathol. 48:283-287.
Kahn, R.P. 1979. Tissue culture applications for plantquarantine, p. 185-201.In: K. Maramorosch and H. Hirumi (eds.). Practical tissue culture application. Academic Press, New York.

Kahn, R.P. 1986. Plant quarantine and international shipment of tissue cultured plants, $\mathrm{p}$ 147-164. In: R. Zimmerman (ed.). Tissue culture as a plant production system for horticultural crops. Martinus Nijhoff., Dordrecht. The Netherlands.

Kahn, R.P. and S.B. Mathur. 1999. Containment facilities and safeguards for exotic plant pathogens and pests. APS Press. St. Paul. Minn.

Kahn, R.P., H.E. Waterworth, and A.G. Gillaspie. 1979. Detection of viruses or virus-like agents in vegetatively propagated plant importations under quarantine in the United States, 19681978. Plant Dis. Rptr. 63:775-779.

Knapp, E., V. Hanzer, H. Weiss, A. da Camara Machado, H. Katinger, and M.L. da Camara Machado. 1997. Characteristics of large-scale production of phytosanitary improved in vitro fruit tree cultivars using in vitro elimination treatments and serodiagnostics, p. 141-147. In: H.W. Dehne (ed.). Diagnosis and identification of plant pathogens,. Kluwer Academic, Dordrecht, The Netherlands.

Lansac, M., L. Chalak, B. Cardona, A. Sorbier, M. Bodin-Ferri, F. Dosba, G. Labonne, L. Quiot, and J.B. Quiot. 1998. In vitro inoculation of Prunus species with plum pox potyvirus. Acta Hort. 472:455-459.

Love, S.L., B.B. Rhodes, and J.W. Moyer. 1987. Meristem tip culture and virus indexing of sweet potatoes, p. 1-31. In: Rpt. Practical manuals for handling crop germplasm in vitro. Intl. Board For Plant Genetic Resources. Rome.

Majumdar, A. 1993. Quarantine to meet the changing scenario in exchange of seed and planting materials. Intl. J. Trop. Plant Dis. 11:127-130.

Mew, T.W., J. Bridge, H. Hibino, J.M. Bonman, and S.D. Merca. 1988. Rice pathogens of quarantine importance, p. 101-115. In: Intl. Rice Research Inst. And United Nations Programme, Rice Seed Health, Proc. Intl. Whshp, Manila.

Mew, T.W., E.D. Gergon, and S.D. Merca. 1990 Impact of seedborne pathogens in rice germplasm exchange. Seed Sci. Technol. 18:441-450.

Mew, T.W. and J.K. Misra. 1994. A manual of rice seed health testing. Intl. Rice Res. Inst., Manila

Miller-Jones, D.N. and P.J. Howell. 1986. Micropropagation as an aid in quarantine procedures for potato material, p. 257-260. In: L.A. Withers and P.G. Alderson (eds.). Plant tissue culture and its agricultural applications. Butterworths, London.

Monette, P.L., S.E. Godkin, and D. James. 1990. Mechanical sap transmission of a closterovirus from in vitro shoot tip cultures of a leafrollaffected grapevine to Nicotiana benthamiana. Vitis 29:49-55.

Navarro, L. 1981. Effect of citrus exocortis viroid (CEV) on root and callus formation by stem tissue of Etrog citron (Citrus medica L) cultured in vitro. Proc. Intl. Soc. Citricult. 1:437439.

Nehra, N.S., K.K. Kartha, C. Stushnoff, and K.L.
Giles. 1992. The influence of plant growth regulator concentrations and callus age on somaclonal variation in callus culture regenerants of strawberry. Plant Cell Tis. Org. Cult. 29:257-268.

Ng, S.Y.C., H.W. Rossel, and G. Thottappilly. 1990. The role of tissue culture in the establishment of disease-free germplasm for international distribution, p. 73-77. In: Integrated pest management for tropical root and tuber crops. Proc. of wkshp. sponser, Ibadan, Nigeria 1987. Intl. Inst. of Trop. Ag. (IITA)

Ng, S.Y.C., G. Thottapilly, and H.W. Rossel. 1992. Tissue culture in disease elimination and mircropropagation, p. 171-182. In: G. Thottappilly, and L.M. Monti (eds.). Enhancing research on tropical crops in Africa, Technical center for Agriculture and Rural Cooperation, Wageningen, The Netherlands.

Parliman, B.P. 1986. Tissue culture techniques and plant introduction/quarantine procedures, p. 271282. In: R. Zimmerman (ed.). Tissue culture as a plant production system for horticultural crops. Martinus Nijhoff, The Netherlands.

Plant Protection Regulat. 1995. Statutes of regulations 195-212, Canada Gaz. Part II. 129(10):13501384.

Postman, J.D., A. Hadidi, and M. Barba. 1995. Elimination of apple scar skin viroid from pears by in vitro thermotherapy and apical meristem culture. Acta Hort. 386:536-543.

Richardson, M. J. 1979. An annotated list of seedborne diseases, 3rd ed. Comwlth. Agr. Bur. Phytopathol. Paper no. 23. Kew, England.

Sanchez, G.E., S.A. Slack, and J.H. Dodds. 1991. Response of selected Solanum species to virus eradication therapy. Amer. Potato J. 68:299-315.

Sansavini, S., P. Rosati, D. Gaggioli, M.F. Toshi 1990; Inheritance and stability of somaclonal variation in micropropagated strawberry. Acta Hort. 280:375-384.

Scowcroft, W.R. 1984. Genetic variability in tissue culture: Impact on germplasm conservation and utilization. Intl. Board For Plant Genetic Resoucres Rpt. 84/152, Rome

Singh, R.P., A. Boucher, T.H. Somerville, and S. Coleman. 1996. Detection of potato viruses A, M, $\mathrm{S}, \mathrm{X}, \mathrm{Y}$ and leafroll and potato spindle tuber viroid from tissue culture plantlets using single leaf discs. Amer. Potato J. 73:101-112.

Spiegel, S., E.A. Frison, and R.H. Converse. 1993. Recent developments in therapy and virus detection procedures for international movement of clonal plant germplasm. Plant Dis. 77:1176-1180.

Thurston, H.D. 1973. Threatening plant diseases. Annu. Rev. Phytopathol. 11:27-52.

Waterworth, H.E. 1993. Processing foreign plant germplasm at the national plant germplasm quarantine center. Plant Dis. 77:854-860.

White, G.A. and H.E. Waterworth. 1996. International exchange of horticultural crop germplasm. HortScience 31:315-321.

Withers, L.A. 1988. The current status of in vitro culture for the international movement of plant germplasm, p. 47-60. In: Conservation and movement of vegetatively propagated germplasm: In vitro culture and disease aspects. Rpt. On in vitro storage conf. Advisory committee. Intl. Board for Plant Genetic Resource, Rome. 